\title{
The Contribution of Medical Tourism to the Economic and Regional Development in Greece
}

\author{
Ioannis Sarantopoulos, \\ University of Peloponnese, Greece
}

Laloumis Demetris, Technological Educational Institute of Athens, Greece

\begin{abstract}
:
The aim of this paper is to investigate the contribution of medical tourism in the economic and tourism development in Greece. For this purpose, a nationwide survey was carried out in 2012. The sample population consisted of executives of 5-star hotels across the country and members of the Hellenic Association of Professional Congress Organizers (HAPCO). Data was gathered by emailing a structured questionnaire to the executives of the abovementioned companies. Descriptive data analyses have been performed. According to our findings, the vast majority of members of 5-star hotels supports that medical tourism could contribute positively to the economic development of the region and to the development of tourism in the country. Majority of executives also believe that investments in medical tourism will be very helpful in attracting tourists and stimulating economic development. The finding of this research indicates that the medical tourism in Greece are perceived by the Greece hoteliers and congress organisers as an effective mean of tourism and economic growth which could facilitate the way out of economic crisis.
\end{abstract}

Paper type: Research paper

Keywords: Medical Tourism, Globalised Healthcare, Economic and Regional Development, International Travel, Perceived Market Attractiveness, Greece 


\section{Introduction}

Medical tourism is a subset of the tourism industry, where people travel internationally to receive medical treatment as part of their travel (Connell, 2011). Travel for health reasons is not a new phenomenon and it has long been recorded as a key driver of visitors to spa towns. The emergence of spa towns in the $17^{\text {th }}$ century like Bath in England and Caldas de Monchique in Portugal attracted affluent people from all over the Europe. In later centuries, with the reduced cost of travelling and increased convenience of commuting, many people travel for the purpose of procuring and receiving medical treatments -- including dental and surgical care.

Since the late $19^{\text {th }}$ century, patients from developing countries visited developed countries for better healthcare services or specialised medical treatments that are not available in their home countries (Horowitz et al., 2007). At the same time, tourists from the western countries have expressed interest in alternative therapies offered in Asian countries, such as ayurvedic practices in India, shiatsu in Japan and Chinese acupuncture (Heung et al., 2011). More recently, there is a growing number of citizens from the developed countries travelled abroad in order to receive healthcare services such as plastic surgery, fertility treatment, dental reconstruction, and other treatments that are not covered by health insurance or national health programmes (Horowitz et al., 2007). Certain medical procedures -- such as abortion, stem-cell transplant and sex-change operation -- are not available in their home country which also encourages people to have medical services in other countries (Connell, 2011). Another reason for patients to have offshore medical treatment is the circumvent delays and long-waiting lists (Horowitz et al., 2007). Perhaps the most influential factor that motivates people to have offshore healthcare services is the comparatively low-cost medical treatment and competitive travel cost (Connell, 2011; Heung et al., 2011; Horowitz et al., 2007). Some scholars point out that medical tourism presents as an option for public health system to reduce government expenditure on healthcare (Baker 2010; Connell, 2011; Mattoo and Rathindran, 2006). For example, if one in ten US patients choose to have medical treatment abroad would results in savings of $\$ 1.4$ billion annually (Mattoo and Rathindran, 2006).

Greece certainly has the potential to further develop its medical tourism credentials. The country offers high-quality and competitive priced medical treatments (Skountridaki, 2015), a great cultural heritage, a mild climate, Mediterranean diet, and an abundance of natural resources suitable for healing and recreation purposes (Stathi and Avgerinos, 2001). In 2014, international arrivals to Greece increased by 23 percent, from 17 million to 22 million visitors (United Nations World Tourism Organisation, 2015). According to the United Nations World Tourism Organization (2014), the growth of the tourism market in Greece is the result of the following factors: a robust tourism policy, implementation of competitive measures and the capacity of the private sector to adjust to a fast changing market in a timely manner.

However, medical tourism is still at its infancy stage in Greece (Skountridaki, 2015) and it has received little attention from the industry players and authorities. More importantly, there is a lack of empirical studies to evaluate the potential for medical tourism in Greece. This paper thus takes an exploratory approach to investigate the perception of hoteliers and tourism-related professionals regarding the prospect of medical tourism in Greece. 


\section{The Economic Dimension of Medical Tourism}

The internationalisation of the healthcare services has developed a new pattern of delivering and consuming healthcare-related goods and services over the past century. The liberalisation of trade in the healthcare sector has also attracted growing interest of foreign direct investment, entrepreneurial-minded healthcare professionals (Skountridaki, 2015), and people who seek for medical treatments in other countries. India is an exemplary here. In 2009, the estimated income generated by medical tourism is INR 9,781 million and the value doubled in 2014, reaching INR 23,019 million (Euromonitor, 2015). According to Burns (2015), the success of India in promoting medical tourism can be attributed to the private sector efforts in building and developing healthcare infrastructure as well as facilitating patient referrals to Indian hospitals. Entrepreneurial-minded doctors such as Dr Devi Shetty and Dr. Govindappa Venkataswamy have built eye hospitals and health cities in India (Burns, 2015; Rangan and Thulasiraj, 2007), attracting patients from all around the world to receive quality medical treatments at affordable price.

Despite the macro and microeconomic benefits of medical tourism, there has been a lack of systematic records which accurately reflect the size and contribution of medical tourism to economic and regional development. Mainly, this is due to privacy and data protection legislation, access to confidential data is prohibited which makes the market evaluation and forecast further problematic. For that reason, there remains disparity in determining the size of the industry (Lunt et al., 2011). Nonetheless, the growth rates or revenue generated by medical tourism are speculative and optimistic (Connell, 2013). Nearly all estimates suggest that medical tourists spend more than tourists (Connell, 2011). According to Turner (2007), a medical tourist spends about three times more than a normal tourist in Singapore. A study investigating spending behaviour of medical tourists in Malaysia found that the total expenditure of medical tourists is 12 times higher than leisure-oriented tourists (Musa et al., 2012: 538). The main component of a medical travel trip is the cost of medical treatment, followed by international airfares, and accommodation, organised tours, shopping, food and beverage, and domestic transportation (Musa et al., 2012). From the list of expenditure occurred during a medical travel, it can be seen that nearly half of the expenses are related to healthcare services and the remaining expenses are related to tourism. Moreover, medical tourists are typically accompanied with at least one person and they tend to stay longer than leisure tourists (Connell, 2011; Lautier, 2014; Musa et al., 2012); indicating that the total cost of a medical travel trip is significantly higher than a leisure travel.

Medical tourism has the potential to influence many different parties and stakeholders, including the career opportunities of healthcare professionals, the life expectancy of patients travelling abroad, the national laws on medical ethics and data protection, and last but not least, the income opportunities for hospitality sector. In reference to Lautier (2014), approximately 37,000 jobs are created by medical tourism in Tunisia where over 19,000 jobs are related to tourism activities. 


\section{Globalisation and Medical Tourism}

Globalisation is driven by a number of factors: economic development, technological advances, political forces, cultural values and beliefs, social norms and environmental changes (Lee, 2000). As part of the process of globalisation, these factors affect both indirectly and directly on healthcare at different levels. At individual level, globalisation can change the life of patients travelling abroad and increase household incomes for healthcare professionals (Skountridaki, 2015). At organisational level, globalisation can affect the resources of healthcare systems and supply of healthcare professionals through patient mobility (Saker et al., 2004). At national level, globalisation can alter the legal framework related to cross-border healthcare services (Vidalis and Kyriakaki, 2014) and government health expenditure (Mattoo and Rathindran, 2006). Globalisation therefore, can trigger a series of changes to the individuals and society at different levels.

To a great extent, the development of General Agreement on Trade and Services by the World Trade Organisation (WTO) has accelerated the free movement of healthcare related goods and services in the past three decades (Lunt et al., 2013). The liberalisation of the trade in healthcare takes a number of different forms, including cross-border healthcare services, foreign direct investment in pharmaceutical and healthcare sector, professional mobility, and perhaps more evidently, medical tourism where people travel for health and wellbeing purposes. For some, the internationalisation of healthcare services represents an entrepreneurial opportunity while some see it as a threat to their professions (Skountridaki, 2015).

The liberalisation of the healthcare sector among the European regions resulted in the cross-border movement of patients to seek and receive medical care. The European Commission has introduced a set of guidelines to encourage patient movement (Vidalis and Kyriakaki, 2014) with the mandate that every EU citizen has the right to seek treatments and travel freely for medical reasons in other EU countries. At the same time, significant changes were made in public health insurance in order to facilitate the movement of patients within the European Union (EU) countries. In 2011, the EU Directive on cross-border healthcare was passed. The EU Directive grants a right for all EU citizens to procure healthcare services across the EU countries and to apply for reimbursement from the national health system in their home countries. However, the number of patients asserting the EU rights is relatively low due to lack of financial incentives (Lunt, 2015).

One implication of the trade liberalised in healthcare is the intensified competition among healthcare industry at both national and international levels. Various countries recognise the prospects of medical tourism. The Indian, Thai, Singaporean, Malaysian governments have all sought to promote their nations as medical tourism destinations (Burns, 2015; Heung et al., 2011; Pocock and Phua 2011; Musa et al., 2012). The South East Asian countries - namely Thailand, Singapore, and Malaysia - have introduced medical tourist visas to cater for the growing number of medical tourists (Pocock and Phua 2011). Similarly, the Indian government also introduced medical visas for foreigners (Burns, 2015). In addition to that, the Indian authorities have implemented initiatives to modernise and accredit complementary and alternative therapies (e.g. ayurvedic, unani, siddha, homeopathy) to promote healthcare industry in the country (Burns, 2015).

The Greek healthcare sector is remarkably developed and this is evident in the 
oversupply of medical doctors in Greece (Skountridaki, 2015). In 2012, Greece has the highest number of doctors per capita among OECD countries, with 6.2 doctors per 1000 inhabitants, nearly twice the EU average of 3.4 (OECD, 2014). As the global consumers increasingly become more health and cost conscious, the future of medical tourism in Greece is fairly optimistic. Nevertheless, the further development and growth of medical tourism will be determined by the coordinated efforts of multiple stakeholders, especially a simplification of the "procedural" part of healthcare legislation into the Greek legal system (Vidalis and Kyriakaki, 2014).

Therefore, it becomes worthwhile to understand the perception of practitioners in tourism industry with regards to medical tourism. In particular, do they believe medical tourism can improve economic and regional development? Do they have interest to invest in medical tourism? This paper seeks to address this gap in the literature and attempt to provide some resolution of these questions.

\section{Research Method}

A nationwide survey was carried out in 2012. The target population consisted of all the 337 5-star hotels across the country and 28 companies-members of the Hellenic Association of Professional Congress Organizers (HAPCO). Data was gathered by emailing a structured questionnaire to the executives of the abovementioned companies. The questionnaire investigates the perception and beliefs of executives regarding the characteristics of the tourism facilities of their company, their evaluation of the existing medical tourist infrastructure in Greece and perspectives for future investment in the field. At first, a pilot survey was conducted so that the initial questionnaire would be corrected and rendered perfectly understandable. The pilot survey took place at 3 hotels and 2 member companies of the Hellenic Association of Professional Congress Organizers (HAPCO). The questionnaire was emailed to responders and it was sent back the same way. The questionnaire was based on academic literature (Cohen et al. 2013; Clark-Carter, 2004) with adjustments to the context of Greek tourism and consisted of three parts. The first part includes respondent demographic data; the second part contains questions regarding medical tourism and the economy, while the third includes questions related to the funding of medical tourism.

\section{Results}

A total of 177 hotels (of 337 contacted) and 15 members of HAPCO executives (of 28 contacted) responded and completed the survey. With thirteen non respondents, the response rate for the HAPCO executives is $53.6 \%$. In a similar fashion, the response rate for the hoteliers is $52.5 \%$ with 160 non-respondents. The response rates for both samples are quite favourable because response rate in some postal research is about 20-30\% (Cohen et al., 2013: 263). The characteristics of the whole sample are presented in table 1 . 
Table 1: Characteristics of the sample $(n=192)$

\begin{tabular}{lrr}
\hline \multicolumn{1}{c}{ Total number } & Percentage \\
\hline Gender & & \\
Male & 152 & 79.2 \\
Female & 40 & 20.8 \\
Age & & \\
$20-35$ & 38 & 19.8 \\
$36-45$ & 72 & 37.5 \\
$46-55$ & 76 & 39.6 \\
$56+$ & 6 & 3.1 \\
Education & & \\
Master degree & 75 & 39.1 \\
Bachelor degree & 105 & 54.7 \\
Certificate/ Diploma & 12 & 6.3 \\
Position & & \\
Owner & 67 & 35.3 \\
Executives & 113 & 59.5 \\
Tour-Operator & 4 & 21.1 \\
Other & 6 & 3.2
\end{tabular}

As indicated in table 1 , nearly $80 \%$ of the respondents were men and only one fifth of the respondents were women. The ages of the respondents vary between 20 years and 55 years and above with the majority being in the younger age group. Over $75 \%$ of the respondents are aged between 36 years and 55 years with almost $3 \%$ being over 56 years and approximately $20 \%$ of the respondents aged between 20 and 35 years. Table 1 also showed that the respondents of the survey are highly educated: $6.3 \%$ of the respondents have secondary education and over $90 \%$ of the respondents have tertiary education. And last but not least, the majority of the respondents hold the tile executives $(59.5 \%)$ or hotel owner $(35.3 \%)$. To sum up, the respondents were mostly men, aged between 20 and 55 years old, highly educated, and most importantly, they have great influence in making decision for their corporations.

Respondents were asked about the impact of the economic crisis to their businesses. Table 2 shows the percentage of respondents answering the financial recession as being 'impactful' and 'no impact' to their businesses. Over $90 \%$ of the respondents $(93.8 \%)$ answered that the hotel that they are working for have been affected by the economic crisis, while only $4.7 \%$ said otherwise: their working organisation not been affected by the economic crisis. Also, $1.6 \%$ of the responders refused to answer or they did not have an opinion on the issue. It can be noticed from the above that the economic crisis has affected the tourism companies negatively. 
Table 2: The impact of the economic crisis on business

\begin{tabular}{lr}
\hline & Percentage \\
\hline No & 4.7 \\
Yes & 93.8 \\
I don't know/ skipped & 1.6
\end{tabular}

Table 3 presents the perception of the respondents towards medical tourism. The majority of executives evaluated highly that medical tourism could contribute positively to economic growth in the region (90.2\%) and the development of tourism in the country $(97.2 \%)$.

Table 3: The Contribution of the Medical Tourism

\begin{tabular}{lccccc}
\hline & Little & Moderate & A Lot & $\begin{array}{c}\text { Very } \\
\text { Much }\end{array}$ & $\begin{array}{c}\text { I don't } \\
\text { know/ } \\
\text { Skipped }\end{array}$ \\
\hline $\begin{array}{l}\text { Medical tourism could contribute } \\
\text { positively to the economic } \\
\text { development of the region? }\end{array}$ & $0 \%$ & $8.9 \%$ & $56.3 \%$ & $33.9 \%$ & $1 \%$ \\
$\begin{array}{l}\text { Do you believe that medical tourism } \\
\text { can contribute to tourism development }\end{array}$ & $0 \%$ & $2.1 \%$ & $45.3 \%$ & $52.6 \%$ & $0 \%$
\end{tabular}

in the country?

The growth of the tourism industry is imperative for regional development. Tourist visitation can also increase demand and use for public facilities such as gardens, toilets, car parks, parks, road infrastructures, etc. Infrastructure of a country is a fundamental factor for travellers in deciding their destination. A number of scholars (Burns, 20015; Connell, 2011; Heung et al., 2011; Stathi and Avgerinos, 2001) have cited the physical infrastructure and public facilities of a country contribute to the one of the key determinants of the destination attractiveness. The authorities in Greece have long recognised the significance of infrastructure in promoting tourism development. Tourism infrastructure in Greece has been attracting massive investment over the past decades (PwC, 2014). This is evident in the perception of the respondents of the survey where three quarters of the respondents $(77.6 \%)$ believe that the effect of infrastructure on tourist arrivals is influential and local support for medical tourism is quite favourable.

Table 4: Support from the local market

\begin{tabular}{lcccc}
\hline & Little & Moderate & A Lot & $\begin{array}{c}\text { Very } \\
\text { Much }\end{array}$ \\
\hline $\begin{array}{l}\text { Can the local market support medical tourism } \\
\text { with related infrastructures (banks, recreation }\end{array}$ & $8.3 \%$ & $14.1 \%$ & $34.4 \%$ & $43.2 \%$
\end{tabular}

areas, accommodation, etc.)?

Table 5 indicates the willingness of respondents to invest in medical tourism while table 6 presents the perception of the respondents regarding the view that investing in medical tourism could attract more international visitors. While less than $10 \%$ of them responded negatively, over $80 \%$ of them had a positive 
evaluation of medical tourism. In particular, $81 \%$ of the respondents indicated their interest to invest in medical tourism and $95.3 \%$ of the respondents believe that investment in medical tourism could attract more tourists to the country. On the contrary, $7.4 \%$ of the respondents did not express their interest to invest in medical tourism and $4.2 \%$ of the respondents perceive medical tourism has little or no impact on attracting tourists to the country.

Table 5: Willingness to invest in medical tourism

\begin{tabular}{lr}
\hline & Percentage \\
\hline No & 7.4 \\
Yes & 81 \\
I don't know/ skipped & 11.6
\end{tabular}

Taking these tables together, the prospect of medical tourism is quite favourable in that top management in the tourism related industry are willing to invest in medical tourism and medical tourism is perceived as positive influence to the economic and regional development.

Table 6: Investing medical tourism can attract more international visitors

\begin{tabular}{lr} 
& Percentage \\
\hline Little & 1.6 \\
Moderate & 2.6 \\
A Lot & 46.6 \\
Very Much & 48.7 \\
I don't know/ skipped & 0.5
\end{tabular}

The contribution of the healthcare exports to tourism industry is presented in table 7 . Over $90 \%$ of the executives $(92.2 \%)$ evaluated highly regarding the contribution of healthcare exports to the tourism industry, while $3.7 \%$ of the respondents think that the contribution of healthcare exports to tourism industry is moderate. Only $4.2 \%$ of the respondents think that the contribution of healthcare exports to tourism industry is minimal. This finding is parallel with the comments of (Connell, 2013) in that the whole infrastructure of the tourist industry (e.g. airlines, hotels, restaurants, domestic transportation, travel agents) benefits considerably from medical tourism. Moreover, service quality effect on satisfaction and word of mouth in the healthcare industry. Well-treated foreign patients will attract more international arrivals seeking fore quality medical care (Lautier, 2014).

Table 7: Perceived contribution of healthcare export to tourism industry

\begin{tabular}{lr}
\hline & Percentage \\
\hline Little & 4.2 \\
Moderate & 3.7 \\
A Lot & 48.7 \\
Very Much & 43.5
\end{tabular}




\section{Discussion}

The purpose of this study was to investigate the contribution of medical tourism in the economic and tourism development in Greece. A nationwide survey was carried out. The target population consisted of all the 5-star hotels across the country and the companies-members of the Hellenic Association of Professional Congress Organizers (HAPCO).

The majority of respondents $(93.8 \%)$ revealed that their companies have been affected by the economic crisis. Over $90 \%$ of the respondents believe that medical tourism could contribute positively to economic growth and regional development. This finding is consistent with the work of Lautier (2014) which found that medical tourism could create job opportunities for the medical tourism destination and promote economic development in the country.

Furthermore, over three quarters of the respondents (77.6\%) strongly believe that the infrastructures for health tourism are quite supportive and favourable and $95.3 \%$ of the respondents think that investments in medical tourism will help in attracting tourists. An important element of this research is the willingness of top management in tourism related organisations to invest in medical tourism. Four fifth of the respondents $(81 \%)$ expressed their interest to invest in medical tourism. This finding is in line with the work of Burns (2015) which found that investment from the private sector contributes to the success if medical tourism in India.

And last but not least, $92.2 \%$ of the respondents think that medical tourism could contribute to the development of tourism in Greece. Taking these together, it can be seen that the industry experts have high expectation and beliefs towards Greek medical tourism. Greece has several relative advantages against its neighbours, including the long established Hippocratic medicine, resourceful natural environment, rich cultural heritage, mild climate, modernised healthcare infrastructure, and most importantly, it has the highest number of doctor per capita (OECD , 2014). The growth of this sector will bring prosperity to the country.

\section{Conclusion}

The outcome from the data analysis was that the major players in the Greek tourism industry believe that medical tourism can contribute positively to the economic and regional development of the country. The majority of the respondents strongly believe that medical tourism can help to boost economic development and investment in medical tourism can attract more tourists to the country. Over half of the responded executives expressed their interest to invest in medical tourism.

Greece is particularly appealing for visitors who seek to combine both physical and mental revival. And thus medical tourism has a great potential in Greece and it should constitute a fast growing industry which could help to promote economic and regional development in the country. This research presented a favourable views from the key players in Greek tourism industry, which drew an initial picture of the medical tourism in Greece, highlighting the need for further future research. 


\section{References}

1. Baker, D. (2010), "Globalizing healthcare: A prescription with benefits", $O E C D$ Observer. Available from: http://www.oecdobserver.org/news/printpage.php/aid/3323/Globalising healthcare :_A_prescription_with_benefits.html (accessed on 1 October 2015).

2. Burns, L. R. (2015), "Medical tourism opportunities and challenges: Illustration from US-India trade", International Journal Of Healthcare Management, Vol. 8, No. 1, pp. 15-26. https://doi.org/10.1179/2047971914Y.0000000091

3. Clark-Carter, D. (2004), Quantitative psychological research. New York: Psychology Press

4. Cohen, L., Manion, L., Morrion, K. (2013), Research Methods in Education. London: Routledge.

5. Connell, J. (2011), Medical tourism, Cambridge: CABI Publishing.

6. Connell J. (2013), “Contemporary medical tourism: Conceptualisation, culture and commodification", Tourism Management, Vol. 34, pp. 1-13. https://doi.org/10.1016/j.tourman.2012.05.009

7. Euromonitor (2015), Travel in India: Industry Overview, Euromonitor International.

8. Heung CS V., Kucukusta D, Song H (2011), "Medical tourism development in Hong Kong: An assessment of the barriers", Tourism Management, Vol. 32, No. 5, pp. 995-1005. https://doi.org/10.1016/j.tourman.2010.08.012

9. Horowitz M.D., Rosensweig J.A., Jones C.A., (2007), "Medical Tourism: Globalization of the Healthcare Marketplace", Medgenmed Medscape General Medicine, Vol. 9, pp. 33-39.

10. Lautier, M. (2014), "International trade of health services: Global trends and local impact", Health Policy, Vol. 118, No. 1, pp. 105-113. https://doi.org/10.1016/j.healthpol.2014.07.004.

11.Lee K. (2000), "The impact of globalization on public health: implications for the UK Faculty of Public Health Medicine", Journal of Public Health, Vol. 22, No. 3, pp. 253-262. https://doi.org/10.1093/pubmed/22.3.253

12. Lunt N, Smith R, Exworthy M, Green S, Horsfall D, and Mannion R. (2011), Medical tourism: treatments, markets and health system implications: a scoping review. Geneva: OECD.

13.Lunt T. N., Mannion R. and Exworthy M. (2013), “A Framework for Exploring the Policy Implications of UK Medical Tourism and International Patient Flows", Social Policy \& Administration, Vol. 47, No. 1, pp. 1-25. https://doi.org/10.1111/j.1467-9515.2011.00833.x 
14. Lunt, N. (2015), “International Patients on Operation Vacation: Medical Refuge and Health System Crisis", International Journal of Health Policy and Management, Vol. 4, No. 5, pp. 323-325. https://doi.org/10.15171/ijhpm.2015.56

15. Mattoo, A. and Rathindran, R. (2006), "How Health Insurance Inhibits Trade In Health Care", Health Affairs, Vol. 25, No. 2, pp. 358-368. https://doi.org/10.1377/hlthaff.25.2.358

16. Musa, G., Thirumoorthi, T., \& Doshi, D. (2012), “Travel behaviour among inbound medical tourists in Kuala Lumpur", Current Issues In Tourism, Vol. 15, No. 6, pp. 525-543. https://doi.org/10.1080/13683500.2011.626847

17. OECD (2014), "Doctors", in OECD/European Union, Health at a Glance: Europe 2014, OECD Publishing, Paris, pp. 62-63.

https://doi.org/10.1787/health_glance_eur-2014-25-en

18. Pocock, NS and Phua KH (2011), "Medical tourism and policy implications for health systems: a conceptual framework from a comparative study of Thailand, Singapore and Malaysia", Globalisation and Health, Vol. 7, pp. 1-12. https://doi.org/10.1186/1744-8603-7-12

19. PwC (2014), Infrastructure Funding the future Greece, available from: https://www.pwc.com/gr/en/publications/assets/infrastructure-funding-the-futureen.pdf (accessed on 1 October 2015).

20. Rangan, V. K. and Thulasiraj, R. D. (2007), "Making Sight Affordable", Innovations: Technology, Governance, Globalization, Vol. 2, No. 4, pp. 35-49. https://doi.org/10.1162/itgg.2007.2.4.35

21. Saker, L. Lee, K. Cannito, B. Gilmore, A. Campbell-Lendrum, D. (2004), "Globalization and infectious diseases: a review of the linkages", Social, Economic and Behavioural Research: Special Topics No.3, World Health Organisation (WHO), available from: www.who.int/tdr/publications/documents/seb_topic3.pdf (accessed on 1 October 2015).

22. Skountridaki, L. (2015), "The internationalisation of healthcare and business aspirations of medical professionals", Sociology, Vol. 49, No. 3, 471-487. https://doi.org/10.1177/0038038514535863

23. Stathi, A. and Avgerinos, A. (2001), "Bathing in the healing waters. A case-study of the development of thermal spas in Greece", World Leisure Journal, Vol. 43, No. 1, pp. 41-51. https://doi.org/10.1080/04419057.2001.9674218

24. Turner, L. (2007), "First World Health Care at Third World Prices': Globalization, Bioethics and Medical Tourism", Biosocieties, Vol. 2, No. 3, 303-325. https://doi.org/10.1017/S1745855207005765 
25. United Nations World Tourism Organisation (2014), UNWTO commends Greece on strong tourism results and high political support to the tourism sector, available from: http://media.unwto.org/press-release/2014-10-27/unwtocommends-greece-strong-tourism-results-and-high-political-support-tou (accessed on 1 October 2015).

26. United Nations World Tourism Organisation (2015), UNWTO Tourism Highlights 2015 edition, UNWTO. https://doi.org/10.18111/9789284416899

27. Vidalis, T. and Kyriakaki, I. (2014), "Cross-border healthcare: Directive 2011/24 and the Greek law", European Journal Of Health Law, Vol. 21, No. 1, pp. 33-45. https://doi.org/10.1163/15718093-12341304 